\title{
Ticari Açıklık, İstihdam ve Enflasyon İlişkisi: Türkiye Örneği a
}

\author{
Deniz Şimşek b, c, C. Erdem Hepaktan ${ }^{d}$
}

\section{Özet}

Bu çalışmada, 2005Q1-2018Q1 dönemlerinde ticari açıklı̆̆ın, enflasyon ve işsizlik gibi makro değişkenler ile ilişkisi incelenmiştir. Analiz için kullanılan değişkenler, TÜIKK ve TCMB resmi sitesinden temin edilmiştir. Analizlere başlamadan önce serilere standart birim kök testleri uygulanmıştır. Birim kök testlerinin ardından, Johansen eş-bütünleşme testi, Granger nedensellik testi yapılarak, değişkenler arasındaki ilişkinin açıklanması için VAR Modeli kurulmuştur. VAR modeline ilişkin etki-tepki ve varyans ayrıştırma sonuçları yorumlanmıştır. Analiz sonuçları, ticari açıklık ile enflasyon arasında ters yönlü bir ilişki olduğunu ve ticari açıklık ile işsizlik arasında pozitif yönlü bir ilişki olduğunu göstermektedir. Johansen Eş-bütünleşme testinin bulguları, seriler arasında uzun dönem eş-bütünleşme ilişkisinin olduğunu göstermektedir. Granger Nedensellik testinden elde edilen sonuçlara göre, ticari açıklık ile işsizlik oranı arasında çift yönlü bir nedensellik ilişkisi bulunmaktadır. Enflasyon ve ticari açıklık arasında ise nedensellik ilişkisi bulunmamaktadır.
Anahtar Kelimeler

Ticari Açıkık

İstihdam

Enflasyon

Makale Hakkında

Geliş Tarihi: 02.07.2019

Kabul Tarihi: 29.11.2019

Doi: 10.18026/cbayarsos.585776

\section{The Relationship between Trade Openness, Employment and Inflation: The Case of Turkey}

\begin{abstract}
In this study, the relationship between trade openness and macro variables such as inflation and unemployment in 2005Q1-2018Q1 periods has been examined. The variables used for analysis have been obtained from TurkStat and CBRT official site. Before the analysis is conducted, standard unit root tests are applied to the series. VAR model is established to explain the relationship between variables by doing Johansen cointegration test, Granger causality test. Effect-response and variance parsing results of VAR model are interpreted. The results, indicates that there is an inverse relationship between trade openness and inflation and It indicates a positive relationship between trade openness and unemployment. The findings of cointegration test showed that there was a long run cointegration relationship between the series. According to the results obtained from the Causality test, there is a bi-directional causality relationship between trade openness and unemployment. There isn't a causality relationship between inflation and trade openness.
\end{abstract}

\begin{tabular}{r} 
Keywords \\
\hline Trade Openness \\
Employment \\
Inflation \\
About Article \\
\hline Received: 02.07.2019 \\
Accepted: 29.11 .2019
\end{tabular}

Doi: 10.18026/cbayarsos.585776

\footnotetext{
a Bu çalışma, Deniz Şimşek'in, Doç. Dr. C. Erdem Hepaktan'ın danışmanlığında hazırlanan “Küreselleşen Dünyada Türkiye Ekonomisinde Ticari Açılık, İstihdam Ve Enflasyon Arasındaki İlişki" başlıklı yüksek lisans tezinden türetilmiştir

b İletişim Yazarı deniz.smsk@gmail.com

c İktisat Bölümü Yüksek Lisans Öğrencisi, Manisa Celal Bayar Üniversitesi Sosyal Bilimler Enstitüsü, Manisa, 0000-0003-3867-3393

d Doç. Dr., Manisa Celal Bayar Üniversitesi İktisadi ve İdari Bilimler Fakültesi İktisat Bölümü, Prof. Dr. İlhan Varank Yerleşkesi, Manisa ${ }_{\llcorner} 0000-0002-$ 3522-1941
} 


\section{Giriş}

Ticaretin küreselleşmesi, uluslararası mal ve hizmet ticaretinde görülen artışa paralel olarak, bu alandaki ticari ilişkilerin serbestleşmesine yol açmıştır. Ticaret alanında küreselleşme, ülkeler arasında mal ve hizmet akımları üzerindeki kısıtlamaların kaldırılması veya azaltılması sürecini kapsamaktadır (Seyidoğlu, 2003). Küreselleşmenin etkisi ile 1970'li yıllarda yaşanan dönüşüm, ülkeleri dışa açık ekonomi politikaları uygulamaya itmiştir. Ülkelerin, dışa açık politika uygulamaları, özellikle dış ticaret ilişkilerinde dışa açıklık olarak, önemli bir yere sahiptir. Dışa açılık; bir ülkenin diğer ülkelerle hangi koşullarda bütünleştiğini, dışa ya da içe dönük olarak hangi ekonomi politikasını uyguladığını veya bunlardan hangisine daha fazla önem verdiğini ve birbirleri ile olan ticari ilişkilerinin büyüklüğünü ortaya koymak adına kullanılan bir kavramdır (Şahbaz, Buluş, \& Kaleci, 2016). Ticaretin serbestleşmesi, ithalat ve ihracata karşı yapılan uygulamaların tamamen kaldırılması gerektiğini ifade eder (Saçık, 2009). Ticari açıklık kavramı, ülkelerin dış dünya ile yapılan ticarette ne kadar yer alacağını ifade etmek için kullanılan bir ölçüttür. Ticari açıklık; ülkeler arasında ticareti sınırlandıran görünür ve görünmez engellerin ortadan kaldırılması olarak ifade edilir. Ülkeler için en genel ticari açıklık ölçütü ise, ithalat ve ihracatlarının GSYH'dan aldıkları payla ifade edilmesidir (İlter ve Doğan, 2018).

Ülkeler için, ticari açklı̆̆ın ölçütleri üzerinde de bir fikir birliği sağlanamamıştır. Hesaplanmasının kolaylığı nedeni ile literatürde en çok kullanılan ticari açıklık ölçütü, ihracat ve ithalatın gayri safi yurt içi hasılaya oranı olarak ifade edilir. Aynı zamanda bu oran, bir ülkenin dış ticarete bağımlılığını ölçen bir orandır (Seyidoğlu, 2013). Literatürde ticari açıklık ölçütü olarak, ticaret payları (ihracatın ya da ithalatın GSYH'ya oranı, ihracat ve ithalat toplamının (dış ticaret hacmi) GSYH'ya oranı), tarife oranları, tarife dışı engeller, fiyat temelli ölçütler, bileşik endeksleri, kara borsa primi, ihracat vergileri ve teşvikleri gibi hesaplamalar kullanılmaktadır (Mercan ve Göçer, 2014).

Rose (2002) WTO üyelerinde ticari liberalizm politikaları hakkında yaptığı çalışmasında, ticari dışa açıklığı ölçmek adına kullandığı yöntemleri yedi kategoride ele almıştır. Rose'un ticari açıklık göstergeleri; Ticaret Yoğunluk Oranı (Ticaret Payları), Tarifeler (Politika Sıklığı Temelli), Tarife Dışı Engeller, Düzeltilmiş Ticaret Akımlar (Ülke Özellikleri İçin), Gayri Resmi veya Niteliksel Önlemler, Bileşik Endeksler ve Fiyat Sonuçlarına Dayanan Önlemler olarak sinıflandırılmaktadır.

Türkiye' de dış ticaret politikaları genellikle, sanayileşme çabaları ile uyumlu politikalar olarak oluşturulmuştur. Türkiye tarihinde, Cumhuriyet'in ilanından bugüne kadar uygulanan diş ticaret politikaları, 1980 yılı öncesi ve sonrası olmak üzere iki dönemde incelenmektedir. 1980 öncesinde, zaman zaman serbest dış ticaret politikaları denenmiş olmakla beraber, ithalata dayalı sanayileşme politikası uygulanmıştır. 1980 sonrasında ise, dış ticaret politikasında değişikliğe gidilmiş ve ihracata dayalı sanayileşme politikası uygulanmaya başlamıştır (Seyidoğlu, 2013).

Çalışmada, Türkiye'de uygulanan dış ticaret politikalarının ne ölçüde ticari açıklığa izin verdiği ve ticari açılık düzeyinin, enflasyon ve işsizlik gibi makro ekonomik göstergelerle ilişkisi incelenmeye çalışılmakta, ticari açıklığın işsizlik ve enflasyon üzerinde bir etkisinin olup olmadığı zaman serileri yardımı ile analiz edilmektedir. Türkiye ekonomisine ait, 
2005Q1-2018Q1 dönemine ilişkin verilerle, ticari açıklı̆ın işsizlik ve enflasyon göstergeleri üzerindeki etkileri VAR modelinden yararlanılarak analiz edilmiştir.

\section{Teorik Çerçeve ve Literatür Taraması}

Türkiye için ticari açılığın, enflasyon ve işsizlik oranları ile ilişkisini analiz etmeden önce, çalışmaya ilişkin teorik bilgilendirme ve literatür çalışmalarına bu başlık altında değinilmektedir.

\section{Teorik Çerçeve}

Literatürde, ülke ekonomilerinde ticari olarak dışa açıklık ve enflasyon arasındaki ilişkiyi ortaya koyan çok sayıda çalışma mevcuttur. Görüş birliği sağlanamasa da, çoğunlukla çalışmalar iki gösterge arasında negatif yönlü bir ilişkinin varlığını ortaya koymuştur. Ticari açıklıkla gelen uzmanlaşma ve ölçek ekonomilerin üretim maliyetlerini düşüreceği görüşü, enflasyonun düşük seviyelerde gerçekleşeceği beklentisini destekler (Güneş ve Korunur, 2013). Romer (1993), ticari olarak dışa açık ekonomilerde, genişleyici para politikaları uygulamalarının kontrollü yapılması ve dış ticaret politikalarının doğru yönetilmesi, enflasyonun düşük seviyelerde gerçekleşeceğini vurgulamıştır.

Literatürde işsizlik alanda yapılan çalışmalar, ihracattaki artı̧̧n, ihracata yönelik üretim yapan sektörlerde istihdamı arttıracağı, işsizlik oranlarını düşüreceği görüşü hakimdir. Teorik olarak ticari açıklık ve işsizlik oranı arasındaki ilişki dış ticaret teorisinin temelini oluşturan Heckscher-Ohlin teoremine dayanmaktadır. Hecksher-Ohlin-Samuelson modeline göre, emek yoğun üretim yapısına sahip bir ülkede dış ticaretteki artışa bağlı artan üretim, emeğin toplam talebini arttıracaktır (Gül ve Kamacı, 2012). Ticari olarak dişa açıklık, işgücü piyasalarını olumlu etkileyebileceği gibi olumsuz etkiler de göstereceği yönünde görüşlerde bulunmaktadır. Bir ülkede, ithalatın, üretime girdi sağlamak amacıyla mı yapıldığı yoksa tüketim malı olarak mı gerçekleştirildiği önemlidir. Bir ülke ara malı değil de, mamul malı ithal etmekte ise, o ülkede istihdamı harekete geçirecek bir etki söz konusu olmayacaktır (Cenger ve Çütcü, 2018).

\section{Literatür Incelemesi}

Ticari açıklık, enflasyon ve işsizlik konusunda literatürde yapılan çalışmalara Tablo 1'de verilmiştir. 
Tablo 1. Literatür Taraması

\begin{tabular}{|c|c|c|c|c|c|c|c|}
\hline \multicolumn{4}{|c|}{ YAZAR } & \multirow{2}{*}{$\begin{array}{l}\text { YIL } \\
\\
\stackrel{\infty}{\stackrel{\sim}{*}}\end{array}$} & \multirow[b]{2}{*}{\begin{tabular}{l}
\multicolumn{1}{c}{ ÇALIŞMANIN } \\
\multicolumn{1}{c}{ BAŞLIĞI } \\
Impact of Trade \\
Openness on \\
Inflation in India: \\
An \\
Autoregressive \\
Distributed Lag \\
(ARDL) \\
Approach
\end{tabular}} & \multirow[b]{2}{*}{ 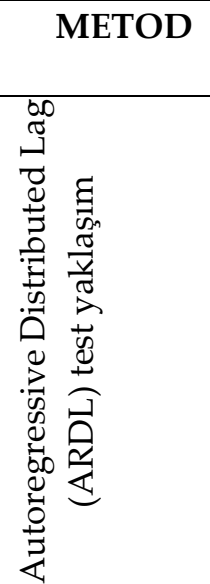 } & \multirow{2}{*}{$\begin{array}{l}\text { SONUÇ } \\
\text { Çalışma sonuçları hem kısa } \\
\text { dönemde hem uzun dönemde } \\
\text { ticari açıklık ve enflasyon } \\
\text { arasındaki ilişkinin pozitif } \\
\text { olduğunu göstermektedir. }\end{array}$} \\
\hline 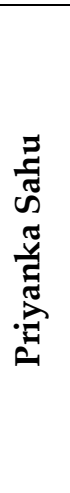 & 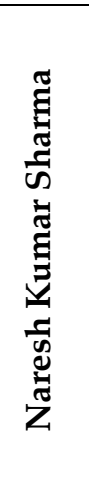 & & & & & & \\
\hline 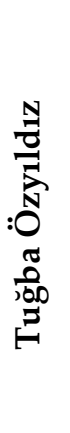 & 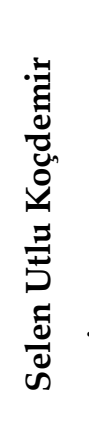 & 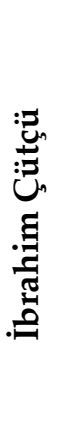 & & $\stackrel{\infty}{\stackrel{\infty}{*}}$ & $\begin{array}{l}\text { Ticari Dışa } \\
\text { Açılığın } \\
\text { Enflasyon ve } \\
\text { Büyüme İle } \\
\text { İlişkisi: Yükselen } \\
\text { Piyasa } \\
\text { Ekonomilerinde } \\
\text { Panel Veri Analizi } \\
\text { Uygulaması }\end{array}$ & 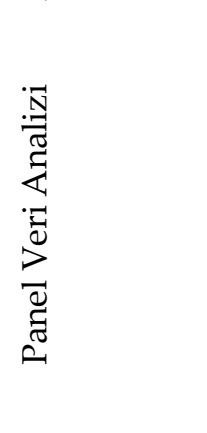 & $\begin{array}{l}\text { Analize sonuçlarına göre; uzun } \\
\text { dönemde ticari açıklık düzeyi } \\
\text { arttıkça enflasyon oranının } \\
\text { düşeceği sonucuna varılmıştır. } \\
\text { Ticari açılık ve enflasyon } \\
\text { oranı arasında ters yönlü ilişki } \\
\text { olduğu görülmüştür. }\end{array}$ \\
\hline 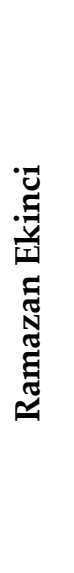 & 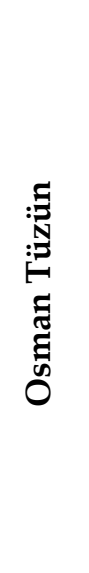 & 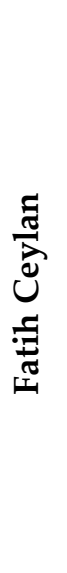 & 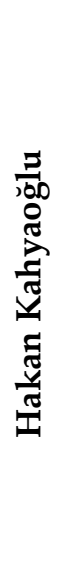 & $\stackrel{ }{\stackrel{\nu}{2}}$ & $\begin{array}{l}\text { Dışa Açılık ile } \\
\text { İşsizlik } \\
\text { Arasındaki İlişki: } \\
\text { Seçilmiş AB } \\
\text { Ülkeleri ve } \\
\text { Türkiye Üzerine } \\
\text { Zamana Göre } \\
\text { Değişen } \\
\text { Parametreli Bir } \\
\text { Analiz }\end{array}$ & 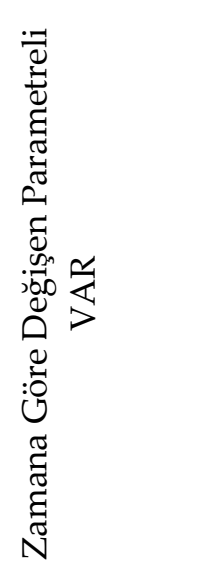 & $\begin{array}{l}\text { AB ülkeleri için bir standart } \\
\text { sapmalık dışa açıklık şokunun } \\
\text { işsizlik oranları üzerindeki } \\
\text { etkisi genellikle artış ve azalış } \\
\text { yönünde olurken, Türkiye için } \\
1996 \text { yllından sonra azalış } \\
\text { yönünde olduğu } \\
\text { gözlemlenmiştir. Bu bakımdan } \\
\text { ihracat artışna yol açabilecek } \\
\text { gelişmelerin işsizliği azaltıcı } \\
\text { etkileri olabileceği } \\
\text { vurgulanmaktadır. }\end{array}$ \\
\hline 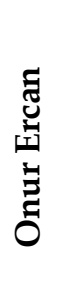 & & & & $\stackrel{\widehat{\ominus}}{\hat{\nu}}$ & $\begin{array}{l}\text { Türkiye'de } \\
\text { Bölgesel Ticari } \\
\text { Açılık İşsizlik } \\
\text { İlişkisi: Düzey } 2 \\
\text { Bölgeleri İçin } \\
\text { Panel Veri Analizi }\end{array}$ & 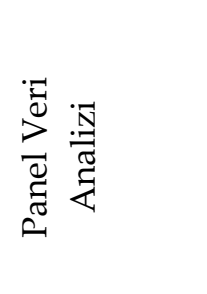 & $\begin{array}{l}\text { Çalışmanın sonucunda ticari } \\
\text { dışa açılık ve işsizlik oranı } \\
\text { arasında negatif yönlü ve } \\
\text { anlamlı bir ilişkinin olduğun } \\
\text { gözlemlenmiştir. }\end{array}$ \\
\hline
\end{tabular}




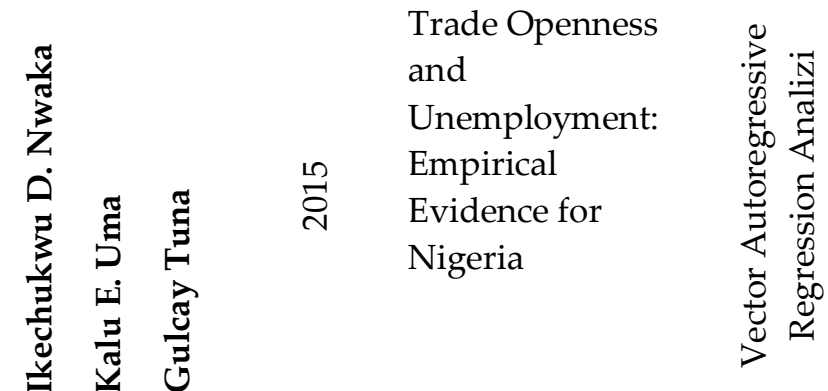

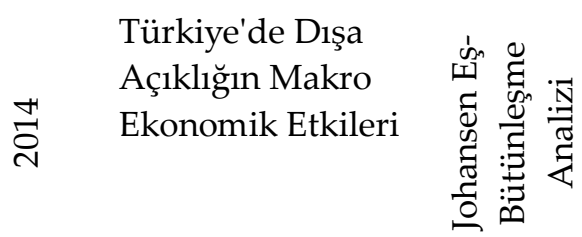

Türkiye

Ekonomisinde

Dışa Açıklık ve

Enflasyon İlişkisi

Üzerine Ampirik

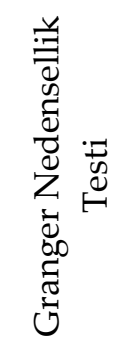

Trade Openness

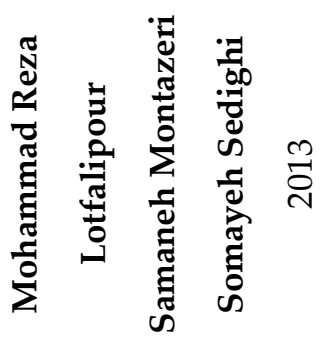

and Inflation.

Evidence from

MENA Region

Countries

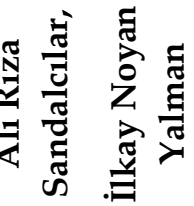

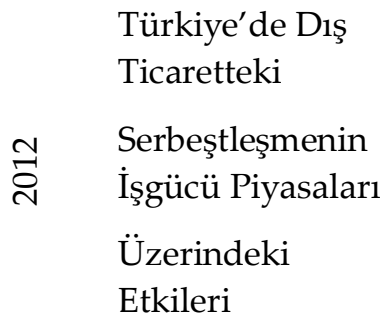

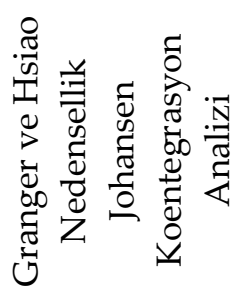

Dış Ticaretin

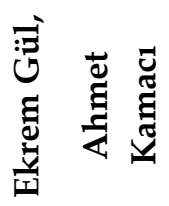

İstihdam

Üzerindeki

Etkileri: Bir Panel

Veri Analizi

Trade Openness

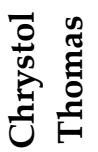

and Inflation:

Panel Data

Evidence For The

Caribbean
Çalışmada

Nijerya

ekonomisinde 1970-2010 yılları için zaman serisi analizi yapılmıştır.

Çalışmanın sonuçlarına göre; ticari açıklık ve işsizlik arasında doğru yönlü ilişki olduğu gözlemlenmiştir.

Çalışma sonuçlarına göre dışa açıklığın söz konusu değişkenler üzerinde pozitif bir etkiye sahip olduğu vurgulanmıştır.

Elde edilen veriler sonucunda kısa dönemde dışa açıklıktan enflasyona doğru negatif yönde bir nedensellik ilişkisi olduğu gözlemlenmiştir. Uzun dönemde ise değişkenler arasında çift yönlü ilişki olduğu vurgulanmıştır.

Çalışmada, dişa açıklık ile enflasyon arasındaki ilişkinin negatif yönlü olduğu tespit edilmiştir.

Nedensellik analizi sonuçlarına göre, Türkiye'de dışa açıklık oranı değişkeninden istihdam oranı değişkenine doğru, negatif yönlü bir nedensellik ilişkisi bulunmuştur.

Çalışmaya göre, gelişmiş ve gelişmekte olan ülkelerde ithalat ve ihracattan işsizliğe doğru bir nedensellik ilişkisi olduğu gözlemlenmiştir.

Çalışmadan elde edilen sonuca göre ticari dışa açıklık ile ortalama enflasyon arasinda pozitif yönlü bir ilişki gözlemlenmiştir. 


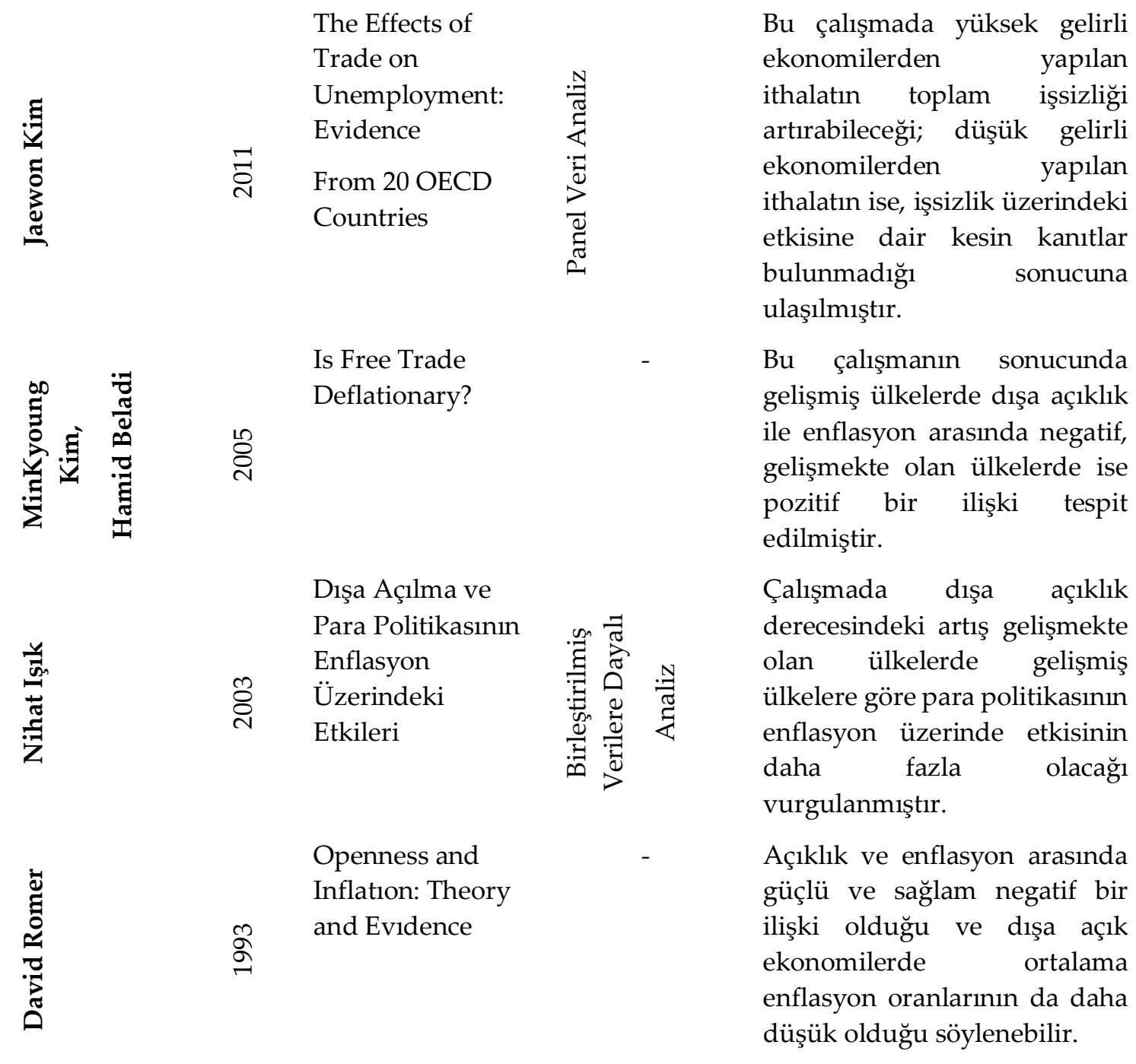

Literatürde yer verilen çalışmaların ticari açıklık ve enflasyon arasındaki ilişkinin yönü konusunda ortak bir görüşü bulunmamaktadır. Çalışmaların bir kısmı ticari açıklık ve enflasyon arasında ters yönlü ilişki olduğu sonucuna ulaşırken (Özyıldız, Utlu ve Çütçü, 2018; Özdil, 2014; Lotfalipour, Montazeri ve Sedighi,2013; Güneş ve Korunur, 2013; Iş1k, 2003; Romer,1993); bir kısım çalışmalar da bu ilişkinin aynı yönlü olduğu (Sahu ve Sharma, 2018; Thomas, 2012) olduğu sonucuna ulaşmıştır. Kim ve Beladi (2005) çalışmasında, ticari açıklık ve enflasyon arasındaki ilişkinin ülkelerin gelişme düzeylerine göre farklı sonuçlar göstereceği sonucuna varmıştır.

Ticari açıklık ve işsizlik arasındaki ilişkinin yönü konusunda da görüş birliğinin sağlanamadığı görülmektedir. Literatürde, ticari açıklık ve işsizlik arasındaki ilişkinin ters yönlü olduğu görüşünü destekleyen çalışmalar olduğu gibi (Ekinci,2017; Ercan,2017; Özdil, 2014; Gül ve Kamac1, 2012); bu ters yönlü ilişkinin aksine aralarındaki ilişkinin pozitif yönlü olacağ1 yönünde (Sandalcılar ve Yalman, 2012; Nwaka, Uma, \& Gülçay, 2015) çalışmalarda bulunmaktadır.

\section{Uygulama Yöntem ve Veriler}


Bu çalışmada, Türkiye' de 2005:Q1-2018:Q1 dönemleri arasında ticari açıklık, işsizlik oranı ve enflasyon oranı değişkenlerinin birbirini etkileme gücü test edilecektir. Modele kontrol değişken olarak, dış ticaret haddi ve büyüme değişkenleri de eklenmiştir. Modeldeki tüm seriler, hareketli ortalama yöntemi kullanılarak, mevsimsellikten arındırılmış ve logaritmaları alınmıştır. Tablo 2'de, çalışmaya dahil edilen değişkenlere ait bilgiler verilmiştir.

Tablo 2. Analizde Kullanılan Değişkenlerin Karakteristik Bilgileri

\begin{tabular}{|c|c|c|c|}
\hline $\begin{array}{l}\text { Değişkenler } \\
\text { (2005Q1 -2018Q1) }\end{array}$ & Kisaltma & Açıklama & Kaynak \\
\hline Ticari Açıklık Oranı & TA & (İhracat+İthalat)/GSYH(cari) & TUIK* \\
\hline İşsizlik Oranı & ISO & Yıllık Yüzde Değişim & $\mathrm{TCMB}^{* *}$ \\
\hline \multirow[t]{2}{*}{ Enflasyon Oranı } & ENF & 2003=100 sabitlemesi Kapsamında Çeyrek & $\mathrm{TCMB}^{* *}$ \\
\hline & & Dönemlik Tüketici Fiyat Endeksi & \\
\hline Büyüme & GSYH & Zincirlenmiş Fiyatlarla & $\mathrm{TCMB}^{* *}$ \\
\hline Dış Ticaret Hadleri & DTH & İhraç malı fiyat endeksi/İthal malı fiyat endeksi & TUIKK* \\
\hline
\end{tabular}

*TUIK: Türkiye İstatistik Kurumu

**TCMB: Türkiye Cumhuriyet Merkez Bankası

Zaman serileri ile yapılacak çalışmada, serilerin gelecek dönem bilgisi hakkında güvenilir sonuçlar vermesi önemlidir. Bu nedenle, serilerin, her dönemde aldığ 1 değerinin, kendinden önceki dönemlerde aldığı değerle regresyonunun bulunup bulunmadığı yani durağan olup olmadıkları belirlenmelidir. Durağan olmayan serilerle kurulan model, gerçeği yansıtmayan sonuçlar vermektedir. Değişkenlerin durağanlık düzeyleri, Genişletilmiş Dickey-Fuller (ADF) ve Philips- Perron birim kök sınaması ile araştırılarak, durağanlık seviyesi belirlenmiştir(Tarı, 2010). Serilerin aynı düzeyde durağan olması durumunda değişkenler arasındaki eşbütünleşme ilişkisinin tespiti için, Johansen eş-bütünleşme analizi ve değişkenlerin aralarındaki ilişkilerinin açıklanması için Granger Nedensellik analizi kullanılmıştır. Çalışmada, ticari açıklığın, enflasyon oranı ve işsizlik oranı değişkenleri üzerinde meydana getirdiği etkiyi açıklamak için, VAR modeli analizinden hareketle elde edilen etki-tepki analizi ve varyans ayrıştırma analizi sonuçları değerlendirilmektedir.

\section{Uygulama Bulguları}

Modellere ilişkin ekonometrik sonuçları; Birim Kök Testi, Johansen Eş-bütünleşme Analizi, Granger Nedensellik Testi, Vektör Otoregresif Modeli, Varyans Ayrıştırması ve Etki-Tepki Analizi başlıkları altında verilmektedir. 


\section{Birim Kök Testi}

Zaman serilerinin, her dönemde aldığı değerin, bir önceki dönemde aldığı değeri ile arasında regresyon ilişkisinin olması, yani zaman serisi analizlerinde serilerin durağan olması gerekmektedir. Zaman serisi analizlerinde, durağan olmayan serilerle tahmin edilen modellerle çalışıldığında, sahte regresyon sorunu ile karşılaşılır. Bu sebeple serilerin durağanlaştırılması gerekmektedir (Tarı, 2010). Bu çalışmada, zaman serilerinin durağanlık analizi, "Genişletilmiş Dikey-Fuller" (ADF) ve Philips-Peron (PP) birim kök testleri kullanılarak yapılmıştır. Analizde, elde edilen ADF-t istatistiği ile MacKinnon kritik değerleri arasında karşılaştırma yapılır. ADF-t istatistiği mutlak değeri, MacKinnon kritik değerinden büyükse serinin durağan olduğu, ADF-t istatistiği mutlak değeri, MacKinnon kritik değerinden küçükse serinin durağan olmadığı sonucuna varılır. Serilerin durağan olmadığ durumda, serinin durağanlığı sağlanıncaya kadar serinin farkı alınmalıdır (Karaca, 2003).

ADF ve PP Birim kök testine ilişkin hipotezler aşağıdaki verilmiştir:

$\mathrm{H}_{0}$ : Seri durağan değildir (birim kök içermektedir).

$\mathrm{H}_{1}$ : Seri durağandır (birim kök içermemektedir).

Tablo 3. ADF ve PP Birim Kök Testi Sonuçları

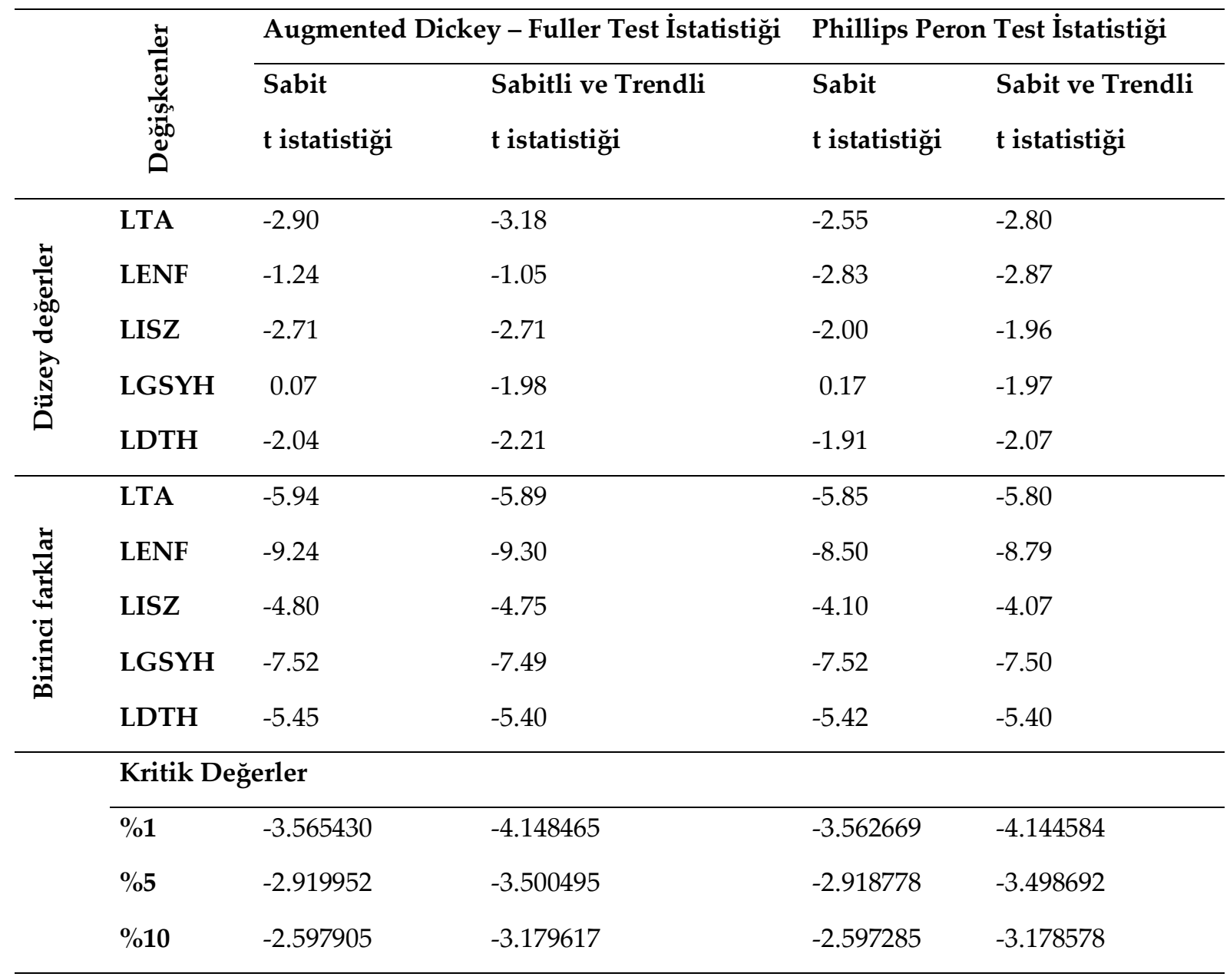


Not1: ADF Testi kritik değerleri \%1, \%5 ve \%10 anlam düzeyindeki MacKinnon (1996) kritik değerlerini ifade etmektedir.

Not2:PP Testi kritik değerleri \%1, \%5 ve \%10 anlam düzeyindeki MacKinnon (1996) kritik değerlerini ifade etmektedir.

ADF ve PP test istatistikleri kritik değerleri, düzey değerlerinde kritik değer istatistiklerinden küçüktür. Yani değişkenler, düzey seviyesinde durağan değildir. Birim kök testi analizi sonucunda değişkenlerin birinci farklarında durağan oldukları görülmüsştür. Bu nedenle, değişkenlere fark işlemi uygulanarak modele dahil edilmiştir.

Değişkenlerin eş-bütünleşme testi yapılmadan önce, değişkenlerin düzey değerleri kullanılarak VAR modelleri kurulmuş ve uygun gecikme sayısı belirlenmiştir.

Tablo 4. VAR Modeli Uygun Gecikme Uzunluğunun Belirlenmesi

\begin{tabular}{lllllll}
\hline Lag & LogL & LR & FPE & AIC & SC & HQ \\
\hline 0 & 216.0702 & NA & $1.25 e-10$ & -8.615111 & -8.422068 & -8.541871 \\
1 & 448.8366 & 408.5287 & $2.61 \mathrm{e}-14$ & -17.09537 & $-15.93711^{*}$ & -16.65593 \\
2 & 476.5193 & 42.93646 & $2.41 \mathrm{e}-14$ & -17.20487 & -15.08140 & -16.39923 \\
3 & 503.8872 & 36.86286 & $2.39 \mathrm{e}-14$ & -17.30152 & -14.21283 & -16.12967 \\
4 & 553.5591 & $56.76795^{*}$ & $1.03 \mathrm{e}-14^{*}$ & $-18.30854^{*}$ & -14.25463 & $-16.77049^{*}$ \\
\hline * Kriter tarafindan seçilen gecikme uzunluğunu & & \\
LR: sequential modified LR test statistic & & \\
FPE: Final prediction error \\
AIC: Akaike information criterion \\
SC: Schwarz information criterion \\
HQ: Hannan-Quinn information criterion
\end{tabular}

Tablo 4'te görüldügü üzere, Modelde LR: sequentialmodified LR test statistic, FPE: Final prediction errorve, AIC: Akaike information criterion ve HQ (Hannan-Quinn Bilgi Kriteri) bilgi kriterlerinin önerdiği 4 gecikmeli modeli benimsenmiştir.

\section{Johansen Eş-Bütünleşme Analizi}

Durağan olmayan zaman serilerinde, serilerin durağan hale getirilmesi için fark işlemi uygulanmaktadır. Serilere uygulanan bu fark işlemi, değişkenler arası uzun dönem bilgisinin kaybolmasına yol açmaktadır. Eş-bütünleşme analizi, durağan olmayan serilerin de durağan doğrusal kombinasyonlarının olabileceğini ve seriler arasında uzun dönemde bir denge ilişkisinin var olabileceğini ifade etmektedir (Tarı, 2010).

Seriler arasında eş-bütünleşme ilişkisinin var olup olmadığı̆, Johansen (1988) ve JohansenJuselius (1990) tarafından geliştirilmiş, Johansen eş-bütünleşme analizi ile yapılmaktadır (Sandalcılar ve Yalman, 2012). Johansen metodunda, koentegrasyon sergileyen vektörlerin sayısını bulmak için, Trace (iz) ve Max-Eigen (maksimum özgül değer) test istatistikleri kullanılmaktadır. Trace ve Max-Eigen test istatistikleri, kritik değerden büyük ise sıfır hipotezi 
reddedilmekte ve alternatif hipotez kabul edilmektedir. Testlerde kullanılabilecek özel kritik değerler, Osterwald-Lenum' da (1992) verilmiştir (Güneş, 2005).

Durağan olmayan zaman serileriyle yapılan regresyon analizleri, sadece bu seriler arasında bir eş bütünleşme ilişkisi varsa gerçek ilişkiyi yansıtabilir (Pesaran, Shin, ve Smith, 2001).

Seriler arasında eş bütünleşmenin varlığı ile ilgili hipotezler aşağıdaki gibi ifade edilmiştir.

$\mathrm{H}_{0}$ : Değişkenler arasında eş-bütünleşme ilişkisi yoktur.

$\mathrm{H}_{1}$ : Değişkenler arasında eş-bütünleşme ilişkisi vardır.

Eş-bütünleşmenin varlığı ve eş-bütünleşme vektör sayısını belirlemek amacıyla elde edilen test sonuçları, Tablo 5'te sunulmuştur.

Tablo 5: Johansen Eş-bütünleşme Test Sonuçları

\begin{tabular}{lccll}
\hline \multicolumn{4}{l}{ Trace İstatistiğine göre Koentegrasyon testi } & \\
\hline Hipotezler & Özdeğer & Trace İstatistiği & \% 5 Kritik Değer & Olasıllk \\
\hline Yok * & 0.713280 & 134.0907 & 79.34145 & 0.0000 \\
En fazla 1 * & 0.506317 & 74.12678 & 55.24578 & 0.0005 \\
En fazla 2 * & 0.415049 & 40.24544 & 35.01090 & 0.0126 \\
En fazla 3 & 0.255454 & 14.50649 & 18.39771 & 0.1611 \\
En fazla 4 & 0.007212 & 0.347444 & 3.841466 & 0.5556 \\
\hline MaxEigene İstatistiğine Göre Koentegrasyon Testi & & \\
\hline Hipotezler & Özdeğer & Max-Özdeğer İstatistiği & \% 5 Kritik Değer & Olasıllk \\
\hline Yok * & 0.713280 & 59.96391 & 37.16359 & 0.0000 \\
En fazla 1 * & 0.506317 & 33.88135 & 30.81507 & 0.0204 \\
En fazla 2 * & 0.415049 & 25.73895 & 24.25202 & 0.0316 \\
En fazla 3 & 0.255454 & 14.15905 & 17.14769 & 0.1294 \\
En fazla 4 & 0.713280 & 59.96391 & 37.16359 & 0.0000 \\
\hline
\end{tabular}

Tablo 5'te yer alan Johansen eş-bütünleşme testi sonucunda, hesaplanan Trace ve Max-Eigen istatistikleri, kritik değerlerden büyük olduğu ve 0.05 olasılık düzeyinde birden fazla vektör varlığ1 görüldüğü için, $\mathrm{H}_{0}$ hipotezi red edilmektedir. Yani, ticari açılık, enflasyon, işsizlik, büyüme ve dış ticaret serileri arasında uzun dönemde bir ilişki bulunmaktadır. Seriler arasında bir adet eş bütünleşik vektörün bulunması, hata düzeltme mekanizması yardımı ile modelin tahmin edilmesini gerektirmektedir.

Normalleştirilmiş eş-bütünleşik denklem, aşağıdaki gibi tahmin edilmiştir.

$T A=-2.04541+0.59 I S Z-0.08 E N F-0.40 G S Y H+0.52 D T H$ 
Uzun dönemde ticari açıklık, enflasyon oranı ve GSYH değişkenleri arasında negatif yönlü ilişki bulunmaktadır. Diğer taraftan, ticari açıklık değişkeniyle işsizlik oranı ve dış ticaret haddi değişkenleri arasında pozitif yönlü bir ilişki olduğu görülmektedir.

Seriler arasında eş-bütünleşme olması, aralarında uzun dönemli bir ilişkinin var olduğunu ifade etmektedir. Engle ve Granger (1987) tarafından geliştirilen Hata Düzeltme Mekanizması (Error-Correction Mechanism, ECM), eş-bütünleşik serilerin uzun dönem dengesinden sapmasını ve her dönem sapmaların ortalamaya nasıl yaklaştığını göstermektedir. Hata düzeltme mekanizması değerinin pozitif olması, dengeden uzaklaştığını gösterirken; negatif çıkması ise, sapmanın uzun dönemde dengeye yaklaştığını göstermektedir (Tarı, 2010).

Tablo 6. Vektör Hata Düzeltme Modeli

\begin{tabular}{llllll}
\hline Hata Düzeltme & $\mathrm{D}(\mathrm{LTA})$ & $\mathrm{D}($ LISZ $)$ & $\mathrm{D}(\mathrm{LENF})$ & $\mathrm{D}(\mathrm{LGSYH})$ & $\mathrm{D}(\mathrm{LDTH})$ \\
\hline CointEq1 & 0.318208 & -0.905995 & 0.472101 & -0.079880 & -0.134967 \\
& $(0.37206)$ & $(0.18238)$ & $(0.96185)$ & $(0.14574)$ & $(0.10946)$ \\
& {$[0.85525]$} & {$[-4.96755]$} & {$[0.49083]$} & {$[-0.54809]$} & {$[-1.23301]$} \\
\hline
\end{tabular}

Denkleme ilişkin hata düzeltme sonuçları, Tablo $6^{\prime}$ da verilmiştir. Tablo $6^{\prime}$ da verilen sonuçlarına bakıldığında, en az bir değişkenin hata düzeltme terimi negatif ve istatistiksel olarak anlamlı olduğu için, hata düzeltme modeli anlamlıdır. Yani, hata düzeltme mekanizması çalışmaktadır ve kısa dönemde meydana gelen sapmalar, sonraki dönemde ya da dönemlerde dengeye gelecektir.

\section{Granger Nedensellik Testi}

Zaman serisi analizlerinde, değişkenler arasındaki sebep sonuç ilişkisi, nedensellik testi ile analiz edilmektedir. Değişkenler arasında bir ilişkinin varlığı ve bu ilişkinin yönünü belirlemek amacıyla, Granger (1996) tarafından kullanılan ve daha sonra geliştirilen Granger nedensellik testi yapılmıştır. Analizinde, tüm serilerin durağan olması gerekmektedir. Fakat serilerin aynı düzeyde durağan olması şartı aranmamaktadır ( Tarı, 2010).

Granger nedensellik testinde, modeldeki bağımsız değişkenin gecikmeli değerlerinin anlamlılığına göre yorumlar yapılır. $X$ ve $Y$ gibi iki değişken arasında, $Y$ değeri, $X$ değişkeninin geçmiş dönem değerleri ile tahmin edilebiliyorsa, $X$ değişkeninden $Y$ değişkenine doğru bir Granger nedensellik ilişkisi olduğu hipotezi kabul edilir. Yani, X, Y'nin Granger nedenidir ve $X \rightarrow Y$ şeklinde gösterilir (Granger,1969). Granger 1969 nedensellik testi denklemleri aşağıdaki gibidir.

$$
\begin{aligned}
& X_{t}=\sum_{\substack{j=1 \\
m}}^{m} \alpha i X_{t-i}+\sum_{j=1}^{m} \beta j Y_{t-j}+\varepsilon_{t} \\
& Y_{t}=\sum_{j=1}^{m} \operatorname{ci~} X_{t-i}+\sum_{j=1}^{m} d j Y_{t-j}+u_{t}
\end{aligned}
$$


Ho: $X, Y^{\prime}$ nin Granger nedeni değildir.

$\mathrm{H}_{1}$ : $\mathrm{X}, \mathrm{Y}^{\prime}$ nin Granger nedenidir.

3 ve 4 nolu denklemlerde, değişkenlerin hata terimleri arasında bir ilişki olmadığı ve gecikme sayılarının eşit kabul edildiği varsayılır. Test sonucu tahmin edilen $\mathrm{F}$ testi sonucu, $\mathrm{F}$ testi tablo değerinden büyükse, sıfır hipotezi red edilmektedir. Yani X, Y'nin Granger nedenidir alternatif hipotezi kabul edilir. Granger nedenselliğinde; $Y$ ile $X$ arasında tek yönlü nedensellik, çift yönlü nedensellik ilişkisi olabileceği gibi, değişkenler arasında nedensellik ilişkisi bulunmadığı da söylenebilir (Tarı 2010).

Değişkenler arasındaki nedensellik ilişkisine ait analiz sonuçları, Tablo 7'de gösterilmektedir.

Tablo 7: Granger Nedensellik Testi Sonuçları

Bağımlı değişken: LTA

\begin{tabular}{llll}
\hline Dişlanan & Ki-kare & sd & olasılık \\
\hline LISZ & 11.93574 & 4 & 0.0178 \\
LENF & 6.647741 & 4 & 0.1557 \\
LGSYH & 14.60098 & 4 & 0.0056 \\
LDTH & 11.46108 & 4 & 0.0218 \\
\hline GENEL & 41.13179 & 16 & 0.0005 \\
\hline
\end{tabular}

Bağımlı değişken: LISZ

\begin{tabular}{llll}
\hline Dışlanan & Ki-kare & sd & Olasıllık \\
\hline D(LTA) & 18.70866 & 4 & 0.0009 \\
D(LENF) & 27.07364 & 4 & 0.0000 \\
D(LGSYH) & 38.81666 & 4 & 0.0000 \\
D(LDTH) & 9.758101 & 4 & 0.0447 \\
\hline All & 84.84604 & 16 & 0.0000
\end{tabular}

Bağımlı değişken: LENF

\begin{tabular}{llll}
\hline Dışlanan & Ki-kare & sd & Olasılık \\
\hline D(LTA) & 0.658170 & 4 & 0.9564 \\
D(LISZ) & 1.153596 & 4 & 0.8857 \\
D(LGSYH) & 3.492187 & 4 & 0.4791 \\
D(LDTH) & 1.801593 & 4 & 0.7722 \\
\hline All & 12.18315 & 16 & 0.7313
\end{tabular}

Bağımlı değişken: LGSYH

D(LTA)

0.931139

4

0.9201 


\begin{tabular}{llll} 
D(LISZ) & 14.03498 & 4 & 0.0072 \\
D(LENF) & 13.48793 & 4 & 0.0091 \\
D(LDTH) & 14.82387 & 4 & 0.0051 \\
\hline All & 40.35527 & 16 & 0.0007 \\
Bağımlı değişken: LDTH & & & \\
D(LTA) & 6.646635 & 4 & 0.1558 \\
\hline D(LISZ) & 4.026275 & 4 & 0.4025 \\
\hline D(LENF) & 6.892078 & 4 & 0.1417 \\
\hline D(LGSYH) & 3.690181 & 4 & 0.4496 \\
\hline All & 23.33304 & 16 & 0.1051
\end{tabular}

Tablo 7'de değişkenler arasında kısa dönem ilişkinin yönünü belirmek için yapılan Granger nedensellik testi sonuçları verilmektedir. Ticari açıklığın bağımlı değişken olduğu denklem için Granger nedensellik sonuçları; işsizlikten, GSYH'dan ve dış ticaret hadlerinden ticari açıklığa doğru bir nedensellik bulunmaktadır. İşsizliğin bağımlı değişken olduğu modelde; tüm değişkenlerden işsizliğe doğru granger nedensellik olduğu tespit edilmiştir. Enflasyonun bağımlı değişken olduğu modelde; değişkenlerden enflasyona doğru nedenselliğe rastlanmamıştır. GSYH'nın bağımlı değişken olduğu modelde, işsizlik oranından, enflasyon oranından ve dış ticaret haddinden GSYH'ya doğru bir nedensellik görülmektedir. Diş ticaret haddinin bağımlı değişken olduğu modelde ise; değişkenlerden dış ticaret haddine doğru bir nedensellik ilişkisine rastlanmamıştır. Sonuçta; ticari açıklık ve işsizlik arasında çift yönlü nedensellik ilişkisi bulunmaktadır. Granger nedensellik testi sonuçlarına göre, enflasyon oranı ve ticari açıklık değişkenleri arasında herhangi bir nedensellik ilişkisine rastlanmamıştır.

\section{Vektör Otoregresif (Vector Autoregression (VAR)) Modeli}

Makro ekonomik modellerde kullanılan değişkenlerin, içsel veya dişsal olup olmadığının bilinmediği durumlarda, VAR modelleri kullanılmaktadır. VAR modelleri, Sims (1980) tarafından, eş anlı denklem modeline alternatif olarak geliştirilmiştir. Sims (1980), eş anlı denklem sistemlerinde değişkenlerin içsel veya dışsal ayrımını eleştirerek, tüm değişkenleri içsel olarak kabul etmektedir (Gujarati, 2004; Tarı, 2010). Var modeli analizi, bir öngörü modeli olmakla birlikte, yapısal analizlerin yorumlanmasında kullanılmaktadır. VAR modellerinde yapısal model üzerinde herhangi bir kısıtlama olmaksızın tüm değişkenler içsel olarak kabul edilmektedir. VAR modeli sonuçlarının tek başına yorumlanması, değişkenler arasındaki ilişkinin açıklanmasında yeterli olmamaktadır. Bu nedenle VAR modelinden elde edilen varyans ayrıştırması ve etki-tepki analizleri sonuçları ile değişkenler arasındaki ilişki yorumlanmaktadır (Tarı, 2010).

Ekonometrik tahminlerde kullanılacak uygun gecikme uzunluğunun değişen varyans ve otokorelasyon sorunu içerip içermediğinin analizi için, modelin bütününün durağanlık analizi yapılmalıdır. AR karakteristik Polinomunun Ters Köklerine ilişkin bilgi şekil 1'de verilmektedir. 


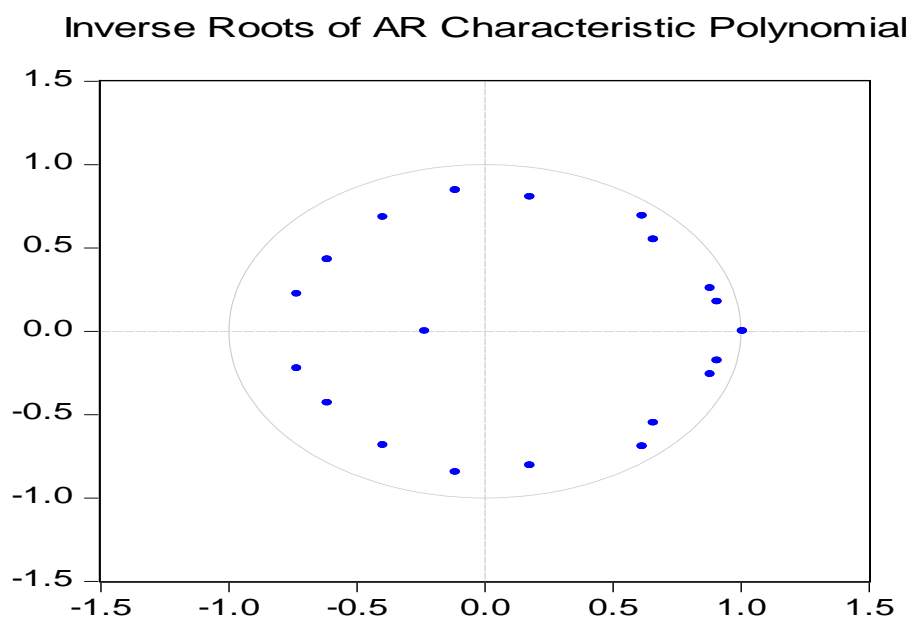

Şekil 1. AR Karakteristik Polinomunun Ters Kökleri

AR karakteristik polinomunun ters köklerinin yer aldığ 1 Şekil 1'de verilen birim çember analizine bakıldığında, tüm ar köklerinin birim çember içinde olduğu görülmektedir. AR karakteristik polinomunun ters köklerinin analizi, VAR modelinin durağan olduğunu ve farklı varyans olmadığını göstermektedir.

VAR modellerine ait analizler öncesinde, Otokorelasyon LM, Normal Dağglım testi ve White Değişen Varyans testleri uygulayarak modelin uygunluğu test edilmektedir. OtokorelasyonLM testi sonuçlarına göre, otokorelasyonun varlığını test etmek için oluşturulan 12 gecikme düzeyinde LM istatistiği 21.36755 (p-değeri: 0.6719) olarak belirlenmekte ve modelde otokorelasyon sorunu bulunmamaktadır. Değişkenlerin normal dağılıp dağılmadığı, JarqueBera test istatistiği ile analiz edilmiştir. Normallik için JB istatistiği 9.296 (p-değeri: 0.5042) olarak hesaplanmış ve değişkenlerin normal dağıldığını ifade eden sıfır hipotezi, \%5 önem düzeyinde kabul edilmektedir. Yani, modele ait değişkenler, normal dağılım göstermektedir. Modelde değişen varyans probleminin saptanması için, White Heteroskedasite Testi uygulanmıştır. White testi sonuçlarına göre, ki-kare değeri 579.5232 (p-değeri: 0.7186) tahmin edilen modelde değişen varyans olmadığını ifade eden $\mathrm{H}_{0}$ hipotezi \% 5 önem düzeyinde red edilmiştir. White farklı varyans testinde, varyansın zamana göre sabit olmadığı, Ho hipotezi reddedilmiştir. Bu durumda, modelde değişen varyans sorunu olmadığı yani hata terimlerinin varyansının aynı olduğu görülmektedir. Test sonuçlarına göre VAR modelin anlamlı olduğu sonucuna ulaşılmıştır.

VAR modelinin yapısal olarak tutarlı olduğu yönündeki analizi tamamladıktan sonra, varyans ayrıştırması ve etki tepki analizi sonuçlarına geçilmiştir.

\section{Varyans Ayrıştırması}

Varyans analizi, her bir değişkenin öngörü hata varyansının, modeldeki her bir değişkene yüklenecek bileşenlerinin oransal olarak ayrıştıılmasıdır. Varyans ayrıştırma, değişkenin varyansında meydana gelecek olan bir değişmenin yüzde kaçının kendisinden, yüzde kaçının diğer değişkenlerden kaynaklandığını göstermektedir. Bir değişkenin varyansında meydana 
gelen değişmenin büyük bölümü kendisindeki şoklardan kaynaklanıyorsa, bu değişkenin dişsal olarak hareket ettiği; diğer değişkenlerden kaynaklanıyora, değişkenin içsel olarak hareket ettiği anlaşılır. Varyans ayrıştırması ile bir değişken üzerinde en çok etkisi olan değişken belirlenirken, değişkenler arasındaki nedensellik ilişkilerinin derecesi hakkında da bilgi edinilir (Tarı, 2010).

Tablo 8. Varyans Ayrıştırması Sonuçları

\begin{tabular}{lllllll}
\hline \multicolumn{6}{l}{ LTA Değişkeni için Varyans Ayrıştırması Sonuçları } \\
\hline Dönem & S.E. & LTA & LISZ & LENF & LGSYH & LDTH \\
\hline 1 & 0.048094 & 100.0000 & 0.000000 & 0.000000 & 0.000000 & 0.000000 \\
2 & 0.062462 & 83.14655 & 10.03734 & 1.304045 & 2.350060 & 3.162007 \\
3 & 0.073151 & 64.18644 & 9.518872 & 6.139608 & 10.85067 & 9.304412 \\
4 & 0.093102 & 40.23127 & 15.90501 & 11.91437 & 8.355620 & 23.59372 \\
5 & 0.106947 & 31.46551 & 22.63944 & 9.887574 & 6.333404 & 29.67407 \\
6 & 0.113680 & 28.61299 & 26.50369 & 8.840325 & 5.644299 & 30.39870 \\
7 & 0.117473 & 27.46913 & 28.53967 & 9.481268 & 5.630106 & 28.87983 \\
8 & 0.117944 & 27.29095 & 28.49520 & 9.573186 & 5.989342 & 28.65132 \\
9 & 0.118641 & 27.01439 & 29.02074 & 9.568599 & 6.007782 & 28.38849 \\
10 & 0.120989 & 26.02930 & 31.06832 & 9.559341 & 5.899670 & 27.44337 \\
\hline
\end{tabular}

LISZ Değişkeni için Varyans Ayrıştırması Sonuçları

\begin{tabular}{lllllll}
\hline Dönem & S.E. & LTA & LISZ & LENF & LGSYH & LDTH \\
\hline 1 & 0.033015 & 11.27345 & 88.72655 & 0.000000 & 0.000000 & 0.000000 \\
2 & 0.065654 & 12.32491 & 80.17270 & 1.374003 & 6.063149 & 0.065239 \\
3 & 0.083556 & 8.103973 & 73.82264 & 2.156962 & 15.87575 & 0.040671 \\
4 & 0.098882 & 6.163257 & 68.36554 & 5.973973 & 16.96566 & 2.531575 \\
5 & 0.114543 & 4.761012 & 65.07807 & 8.037015 & 13.42660 & 8.697305 \\
6 & 0.124015 & 4.061985 & 65.34629 & 7.439394 & 11.60964 & 11.54269 \\
7 & 0.129618 & 3.977133 & 64.95545 & 6.921023 & 11.19765 & 12.94874 \\
8 & 0.132794 & 4.158363 & 63.63395 & 6.803456 & 10.98846 & 14.41577 \\
9 & 0.134297 & 4.108710 & 62.27932 & 6.969006 & 10.80519 & 15.83777 \\
10 & 0.136083 & 4.001927 & 61.38785 & 7.107430 & 11.17274 & 16.33006 \\
\hline
\end{tabular}

LENF Değişkeni için Varyans Ayrıştırması Sonuçları

\begin{tabular}{lllllll}
\hline Dönem & S.E. & LTA & LISZ & LENF & LGSYH & LDTH \\
\hline 1 & 0.142607 & 4.864816 & 0.018736 & 95.11645 & 0.000000 & 0.000000 \\
2 & 0.168208 & 17.06988 & 0.150128 & 81.77902 & 0.970849 & 0.030121
\end{tabular}




\begin{tabular}{lllllll}
3 & 0.184231 & 24.36783 & 0.411839 & 73.26718 & 1.905824 & 0.047330 \\
4 & 0.190018 & 23.35812 & 0.407124 & 72.87463 & 3.185011 & 0.175111 \\
5 & 0.210297 & 21.84712 & 2.494574 & 71.26103 & 3.796982 & 0.600291 \\
6 & 0.230073 & 22.05157 & 10.26220 & 62.29448 & 4.844825 & 0.546927 \\
7 & 0.240839 & 22.16855 & 14.78358 & 57.08527 & 4.994746 & 0.967856 \\
8 & 0.250834 & 20.61171 & 15.96223 & 56.01365 & 5.460010 & 1.952396 \\
9 & 0.257237 & 19.65036 & 15.57978 & 56.24885 & 5.801526 & 2.719487 \\
10 & 0.259975 & 19.93912 & 15.27690 & 55.98084 & 5.718672 & 3.084474 \\
\hline
\end{tabular}

\section{LGSYH Değişkeni için Varyans Ayrıştırması Sonuçları}

\begin{tabular}{lllllll}
\hline Dönem & S.E. & LTA & LISZ & LENF & LGSYH & LDTH \\
\hline 1 & 0.022209 & 8.296838 & 34.69057 & 1.473994 & 55.53860 & 0.000000 \\
2 & 0.030869 & 4.574046 & 54.13805 & 1.342795 & 39.34706 & 0.598054 \\
3 & 0.038433 & 4.127473 & 45.90263 & 7.648201 & 34.04799 & 8.273702 \\
4 & 0.045870 & 5.801296 & 48.00057 & 6.938826 & 27.68214 & 11.57717 \\
5 & 0.053597 & 5.184271 & 53.28864 & 5.142737 & 23.77083 & 12.61352 \\
6 & 0.059210 & 5.214532 & 55.03571 & 4.461102 & 21.61498 & 13.67368 \\
7 & 0.062261 & 5.377098 & 54.75596 & 4.036108 & 21.86112 & 13.96972 \\
8 & 0.064776 & 5.849043 & 53.21733 & 4.454254 & 21.77392 & 14.70545 \\
9 & 0.066755 & 5.895860 & 51.87451 & 5.025480 & 20.99814 & 16.20601 \\
10 & 0.068286 & 6.037529 & 50.33551 & 5.565145 & 20.58977 & 17.47204 \\
\hline
\end{tabular}

\section{LDTH Değişkeni için Varyans Ayrıştırması Sonuçları}

\begin{tabular}{lllllll}
\hline Dönem & S.E. & LTA & LISZ & LENF & LGSYH & LDTH \\
\hline 1 & 0.015170 & 18.39510 & 8.014120 & 0.025813 & 9.821666 & 63.74331 \\
2 & 0.022111 & 25.06068 & 7.363174 & 1.304519 & 6.582161 & 59.68947 \\
3 & 0.026940 & 23.65588 & 5.236674 & 0.958858 & 7.689615 & 62.45897 \\
4 & 0.033313 & 15.95076 & 3.687837 & 6.176528 & 6.100874 & 68.08400 \\
5 & 0.036529 & 13.27311 & 3.452980 & 8.469320 & 5.543724 & 69.26087 \\
6 & 0.038871 & 11.93208 & 3.710524 & 9.542712 & 5.185000 & 69.62969 \\
7 & 0.040518 & 10.98533 & 3.678215 & 9.390763 & 5.350375 & 70.59532 \\
8 & 0.041317 & 11.20552 & 3.628600 & 9.100100 & 5.440975 & 70.62481 \\
9 & 0.042165 & 11.46509 & 4.733483 & 8.775402 & 5.686009 & 69.34002 \\
10 & 0.043472 & 11.52976 & 7.269783 & 8.310799 & 5.975709 & 66.91395 \\
\hline
\end{tabular}

Model'e ait varyans ayrıştırma sonuçları, Tablo 8'de verilmiştir. Ticari açıklık değişkeni varyans ayrıştırma sonuçlarına göre, 10. dönem sonunda, \% 26,03'ü kendinden kaynaklı 
şoklarla açıklanırken, enflasyon değişkenin ticari açıklık değişkenini açıklama gücü \% 9,56 iken, işsizlik oranının \% 31,07, gayri safi yurtiçi hasılanın \% 5,90 ve dış ticaret haddinin $\%$ 27,44 olarak görülmektedir.

Enflasyon oranı değişkeni için varyans ayrıştırma sonuçlarına göre, 1. dönemde değişmelerin \% 95,11'i kendisi tarafından açılanmaktadır. 10. dönem sonunda, enflasyon değişkeninin \% 55,98'i kendinde meydana gelen şoklarla açıklanırken, \% 19,94 ticari açıklık, \% 15,28' si işsizlik oranı, \% 5,72'si gayri safi yurtiçi hasıla, \% 3,08'i diş ticaret haddi değişkeni tarafından açıklanmaktadır.

İşsizlik değişkeni için varyans ayrıştırma sonuçlarına bakıldığında; ilk dönemde yaklaşık \% 88,73 oranında kendinden kaynaklandığ 1 görülmektedir. 10. dönemde, işsizlik oranındaki değişikliğin yaklaşık \% 61,39'u kendisi tarafından açıklanırken, diğer değişkenlerin işsizlik oranını açıklama gücü; \% 4'ü ticari açıklık, \% 7,1'i enflasyon, \% 11,17'si gayri safi yurtiçi hasıla ve $\% 16,33^{\prime}$ ü dış ticaret haddi olarak belirlenmiştir.

Gayrisafi yurtiçi hasıla değişkeninin 10. döneminde meydana gelen değişmelerinin kendisi tarafından açıklanan kısmı, \% 20,58 olarak belirlenmektedir. Ticari açıklık \% 6,04, işsizlik oranı $\% 50,34$, enflasyon \% 5,57 ve dış ticaret haddi ise \% 17,47 oranında GSYH değişkenini açıklama gücüne sahiptir.

Son olarak dış ticaret haddi değişkeninde 10. dönemde ortaya çıkan değişmeler, \% 66,91 oranında kendi yapısından kaynaklı olduğu görülmektedir. Diğer değişkenlerin 10. dönem sonunda dış ticaret haddini açıklama gücüne bakıldığında; ticari açıklık \% 11,53, işsizlik oranı $\% 7,27$, enflasyon oranı $\% 8,31$ ve gayri safi yurtiçi hasıla $\% 5,97$ olarak belirlenmektedir.

\section{Etki-Tepki Analizi}

Etki-tepki analizleri, değişkenlere uygulanan bir birim standart sapmalı şokun, kendisi veya diğer değişkenler üzerindeki etkisini analiz etmektedir (Uysal, Mucuk ve Alptekin, 2008). Etkitepki analizlerinde, bir değişkenin hata teriminde meydana gelecek bir şoka karşılık, diğer değişkenin vereceği tepki belirlenmektedir. Makro ekonomik büyüklüğün üzerinde etkili olabilecek değişkenin hangisi olduğu varyans ayrıştırması ile belirlenirken, bu etkiyi gerçekleştiren değişkenin politika aracı olarak kullanılabilir olup olmadığı ise, etki-tepki fonksiyonları ile belirlenmektedir (Sarı, 2008). Grafikte yer alan sütunlar, şokların meydana geldiği değişkenleri ifade ederken; satırlar ise bu şoklara karşılık değişkenlerin verdiği tepkileri göstermektedir (Tarı, 2010).

Aşağıda, VAR modeli tahmini sonucunda ulaşılan \pm 2 standart hatalık güven aralığındaki etkitepki fonksiyonu grafikleri verilmektedir. 

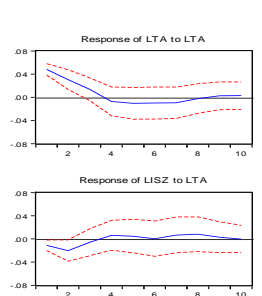

Response of LENF to LT
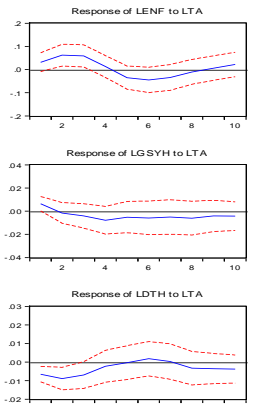

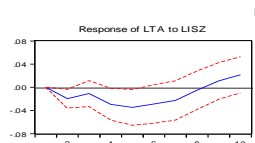

Response of LIsz to LIs

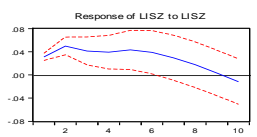

Response of LEN to US
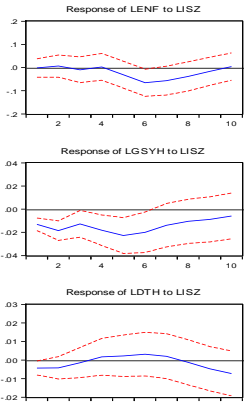
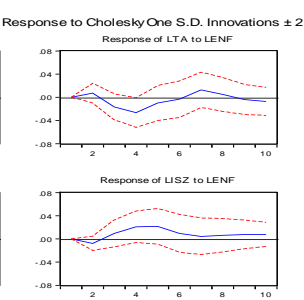

Response of LENF to LEN
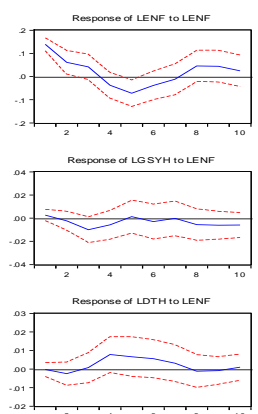
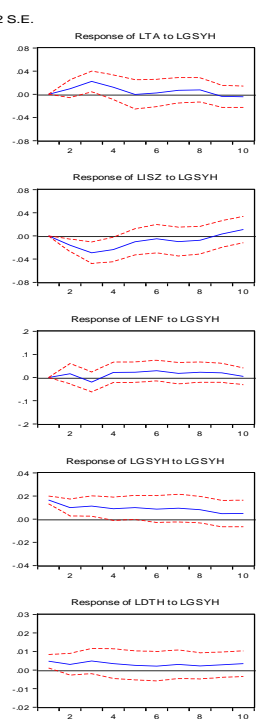
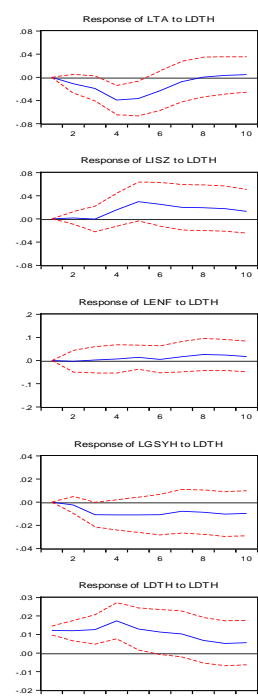

Şekil 2. Model için Etki- Tepki Fonksiyonlar

Model'e ait etki tepki grafikleri, yukarıdaki Şekil 2'te verilmektedir. Değişkenlere ait katsayılar, güven aralığı içinde hareket etmesi nedeniyle anlamlıdır. LTA değişkenine gelen bir birimlik şoka LENF değişkeninin verdiği tepki 3. ve 6. dönemler arasında negatifken, 7. ve 8. dönem sonunda bu tepki pozitife dönmeye başlamış 9. dönemde tekrar negatife dönmüştür. LTA değişkenine gelen bir birimlik şoka LISZ değişkeninin verdiği tepki 8. dönem sonuna kadar negatif ilerlerken, 9. dönemde pozitife dönmekte ve 10. dönem sonunda dengeye ulaşmaktadır. LENF değişkeninde meydana gelen bir birimlik şokun ise, LNTA değişkeni üzerindeki etkisi 5. ve 8. dönemler arasında negatif yönlü iken, 10. dönemde dengeye ulaşmaktadır. LISZ değişkeninde meydana gelen bir birimlik şoka, LNTA değişkeni ilk üç dönemde negatif tepki verirken, enflasyon ise 2 . dönem dişında pozitif tepki göstermektedir. Tüm değişkenler 10. dönemde dengeye gelmektedir.

\section{Sonuç ve Öneriler}

Dünya üzerinde küreselleşme ile birlikte, özellikle gelişmekte olan ülkeler olmak üzere, birçok ülkede enflasyon ve işsizlik önemli bir ekonomik sorun olarak görülmektedir. Bu açıdan, ticari açıklık, enflasyon ve işsizlik oranları arasındaki ilişkinin belirlenmesi, ülkelerin ekonomi politikalarının belirlenmesine katkıda bulunacaktır. Enflasyon ve işsizliğin ticari açıklıkla ilişkisi, her ülkenin sahip olduğu yapısal farklılıklara göre değişim göstermektedir.

Analizin sonuçlarına göre, Türkiye'de ticari açıklık ve enflasyon arasında kısa dönemde bir ilişkinin bulunmadığı, uzun dönemde ise enflasyon oranları arttıkça ticari açıklığın azaldığı, ticari açıklık artarken enflasyonun düştüğü görülmektedir. Diğer taraftan etki tepki sonuçlarına bakıldığında, ticari açıklık değişkeninde meydana gelecek bir şok, enflasyon değişkenini önce azaltmakta sonra arttırmaktadır. Ticari açıklık ve enflasyonun karşılıklı etkilerine bakıldığında, enflasyonun yüksek olduğu ortamda ticari açıklığın azalacağı söylenebilirken, ticari açıklı̆ı̆ ise enflasyon oranındaki etkisi zamana yayılmaktadır. Enflasyonun kontrol altında tutularak, ticari açıklık üzerindeki etkisi bakımından ülke lehine sonuçlar doğurması yönünde politikalar uygulamalıdır. Ülkede enflasyonun uzun vadede kontrol altında tutulması adına, yerli üretim, iç talebi karşılayacak ölçüde arttırılmalıdır. Ülke 
içinde üretimi yapılamayan ya da üretimi yetersiz kalan ürünlerin ithalatı kontrollü bir şekilde serbest bırakılmalıdır. Ayrıca enflasyonun dış ticaret dengesi üzerinde yaptığı baskı, ülkede verimliliğin düşmesine, ekonomide belirsizliğin artmasına ve güven ortamının zarar görmesine yol açmaktadır. Bu durum, Türkiye'nin, uluslararası piyasalarda rekabet gücünü olumsuz etkiler, yapılacak doğrudan yabancı sermaye yatırımlarının ülkeye girişini engeller, istihdamın da olumsuz etkilenmesine yol açar. Bu nedenle, ülkede ekonomik istikrarın sağlanması yönünde adımlar atılmalıdır.

Türkiye' de ticari açıklık ve işsizlik arasında ise, kısa dönemde çift yönlü bir ilişki bulunurken, uzun dönemde, işsizlikte görülecek artışın ticari açıklığı arttıracağı, ticari açıklık oranında bir artışın ise işsizlik oranlarını yükselteceği yönündedir. Ticari açıklık ve işsizlik oranı arasında varlığı kabul edilen ters yönlü ilişki, Türkiye için pozitif çıkmıştır. Bu durumda, her ülkenin kendi ekonomik yapısından kaynaklanan, kendine özgü farklılıklar taşıdığı söylenebilir. Son yıllarda, Türkiye'de, ticari açıklık oranları artarken, ihracatın emek yoğun mallardan, sermaye yoğun mallara kayması, işgücü piyasalarını olumsuz etkileyerek istihdamı düşürmektedir. Türkiye gibi yüksek emek gücüne sahip bir ülkede, istihdam oranlarında bir artışın sağlanması için emek yoğun üretim yapan sektörlerin desteklenmesi, ülkenin sahip olduğu işgücünün niteliklerinin yükseltilmesi adına eğitim sisteminde gerekli düzenlemelerin yapılması, işgücü piyasalarına ilişkin koşulların yeniden gözden geçirilmesi ve istihdam oranını arttıracak politikaların uygulanması önerilmektedir. Ayrıca, Türkiye'de üretimin büyük oranda ara malı ithalatına bağlı olması ve döviz kurunda meydana gelen aleyhte değişimlerin ülkede üretimi olumsuz etkilemesi de, istihdam oranlarının azalmasına yol açmaktadır. Bu nedenle, istikrarlı bir döviz kuru ülkede öncelikle üretimi ve dolaylı olarak istihdamı olumlu etkileyecektir.

Çalışmada elde edilen bulgulara dayanarak, Türkiye'de ticari açıklığın olumlu etkilerinden faydalanmak adına, yerli üretimin desteklenmesi, ihraç ürünlerinin çeşitliliğinin arttırılması, yeni teknolojilerin hızlıca benimsenmesi ve uygulanması, Ar-Ge yatırımlarına yoğunluk verilmesi, ülkenin sahip olduğu beşeri sermayeye yani potansiyel işgücüne yatırım yapılması ve niteliklerinin arttırılması, yabancı sermaye yatırımlarının önünü açacak yapısal reformların yapılması önerilmektedir.

\section{Kaynakça}

Cenger, H., \& Çütcü, İ. (2018). İthalattaki Değişimin Genç İşsizliğe Etkisi: Türkiye Ekonomisi Üzerine Ekonometrik Bir Uygulama. Uluslararası Toplum Araştırmaları Dergisi, 8(Gençlik Araştırmaları Özel Sayısı), 485-503. https://dergipark.org.tr/tr/download/article-file/443838

Ekinci, R., Tüzün, O., Ceylan, F., \& Kahyaoğlu, H. (2017). Dışa Açıklık ile İşsizlik Arasındaki İlişki: Seçilmiş AB Ülkeleri ve Türkiye Üzerine Zamana Göre Değişen Parametreli Bir Analiz . Sosyo-Ekonomi Dergisi, 25(31), 45-73. https://dergipark.org.tr/tr/download/articlefile/263603

Ercan, O. (2017). Türkiye' de Bölgesel Ticari Açıklık-İşsizlik İlişkisi: Düzey 2 Bölgeleri İçin Panel Veri Analizi. Eskişehir Osmangazi Üniversitesi Sosyal Bilimler Enstitüsü, Yayınlanmamış Yüksek Lisans Tezi. Eskişehir. https://tez.yok.gov.tr/UlusalTezMerkezi/tezSorguSonucYeni.jsp 
Granger, C. (1969). Investigating Causal Relations by Econometric Models and Cross-Spectral Methods $\quad$ Econometrica, 424-438. https://www.jstor.org/stable/pdf/1912791.pdf?refreqid=excelsior\%3A76ffdea0254e2c49a1c 61ffbe58201a7

Gujarati, D. N. (2004). Basic Econometrics. U.S.A.: Tata McGraw-Hill Education.

Gül, E., \& Kamacı, A. (2012). Dış Ticaretin İstihdam Üzerindeki Etkileri: Bir Panel Veri Analizi. Anadolu Üniversitesi Sosyal Bilimler Dergisi, 12(4), 23-32. https://earsiv.anadolu.edu.tr/xmlui/bitstream/handle/11421/131/2012-04 02\%5B1\%5D.pdf?sequence $=1$ \&isAllowed $=y$

Güneş, S. (2005). Türkiye'de Nüfus Artışının Ekonomik Büyümeyle İlişkisi Üzerine Ekonomik Bir Analiz. Ankara Üniversitesi Sosyal Bilimler Fakültesi Dergisi, 60(3), 123-136. https://dergipark.org.tr/tr/download/article-file/36095

Güneş, Ş., \& Konur, F. (2013). Türkiye Ekonomisinde Dışa Açılılı ve Enflasyon İlişkisi Üzerine Ampirik Bir Analiz. Eskişehir Osmangazi Üniversitesi İktisadi ve İdari Bilimler Dergisi, 8(2), 720. https://dergipark.org.tr/tr/pub/oguiibf/issue/5714/76485

İlter, Ş., \& Doğan, B. B. (2018). Ticari ve Finansal Dışa Açıklık Oranı İle Ekonomik Büyüme Arasındaki Nedensellik İlişkisi: Türkiye Örneği. Dicle Üniversitesi İktisadi Ve İdari Bilimler Fakültesi Dergisi, 8(15), 89-115. https://dergipark.org.tr/tr/pub/duiibfd/issue/37998/438742

Işık, N. (2003). Dışa Açılma ve Para Politikasının Enflasyon Üzerindeki Etkileri: Bir Uygulama. Ekonomik Yaklaşım Dergisi, 87-96. https://econpapers.repec.org/article/eydeyjrnl/v_3a14_3ay_3a2003_3ai_3a48_3ap_3a8796.htm

Karaca, O. (2003). Türkiye'de Enflasyon-Büyüme İlişkisi: Zaman Serisi Analizi. Doguş $\begin{array}{lll}\text { Üniversitesi Dergisi, 247-255. } & \text { 24), }\end{array}$ https://openaccess.dogus.edu.tr/xmlui/handle/11376/545\#sthash.Z6JtYfab.dpbs

Kim, J. (2011). The Effects of Trade on Unemployment: Evidence From 20 OECD Countries. (S. University, Dü.) Department of Economics Research Papers in Economics, 19, 1-46. https://core.ac.uk/download/pdf/6524509.pdf

Kim, M., \& Beladi, H. (2005). Is Free Trade Deflationary? Economics Letters, 89(3), 343-349. doi:doi.org/10.1016/j.econlet.2005.06.016

Lotfalipour, M. R., Montazeri, S., \& Sedighi, S. (2013). Trade Openness and Inflation. Evidence from MENA Region Countries. Economic Insights-Trends and Challenges, 2(2), 1-11. https://www.researchgate.net/profile/Mohammad_Lotfalipour/publication/261882336_Tra de_Openness_and_Inflation_Evidence_from_MENA_Region_Countries/links/5cc9bae645 85156cd7c19099/Trade-Openness-and-Inflation-Evidence-from-MENA-Region-

Countries.pdf

Mercan, M., \& Göçer, İ. (2014). Ticari Dışa Açıklığın Ekonomik Etkileri: Orta Asya Ülkeleri İçin Ampirik Bir Analiz. Uluslararası Yönetim İktisat ve İşletme Dergisi, 10(22), 27-44. http://apache.beun.edu.tr/index.php/zkesbe/article/view/485

Nwaka, I. D., Uma, K. E., \& Gülçay, T. (2015). Trade Openness and Unemployment: Empirical Evidence for Nigeria. The Economic and Labour Relations Review, 26(1), 117-136. doi:doi.org/10.1177/1035304615571225

Özdil, S. (2014). Türkiye'de Dışa Açıklığın Makro Ekonomik Etkileri. (Yayınlanmamış Yüksek Lisans Tezi, Adnan Menderes Üniversitesi,Sosyal Bilimler Enstitüsü,Aydın). http://adudspace.adu.edu.tr:8080/xmlui/handle/11607/389 
Özyıldız, T., Utlu, S. K., \& Çütçü, İ. (2018). Ticari Dışa Açıklı̆ın Enflasyon ve Büyüme İle İlişkisi Yükselen Piyasa Ekonomilerinde Panel Veri Analizi Uygulaması. Uluslararası Yönetim İktisat ve İşletme Dergisi, 14(2), 335-356. http://ijmeb.org/index.php/zkesbe/article/view/1673

Pesaran, H. M., Shin, Y., \& Smith, R. J. (2001). Bounds Testing Approaches to The Analysis of Level Relationships. Journal of Applied Econometrics, 16(3), 289-326. doi:doi.org/10.1002/jae.616

Romer, D. (1993). Openness and Inflation: Theory and Evidence. The Quarterly Journal Of Economics, 108(4), 869-903. doi:doi.org/10.2307/2118453

Rose, A. K. (2002). Do WTO Members Have More Liberal Trade Policy? Journal of international Economics, 63(2), 209-235. doi:doi.org/10.1016/S0022-1996(03)00071-0

Saçık, S. Y. (2009). Büyümenin Bir Kaynağı Olarak Ticari Dışa Açıklık. Sosyal Ekonomik Araştırmalar Dergisi, 9(18), 273-294. https://dergipark.org.tr/tr/download/article-file/289217

Sahu, P., \& Sharma, N. K. (2018). Impact of Trade Openness on Inflation in India: An Autoregressive Distributed Lag (ARDL) Approach. The Empirical Economics Letters, 17(1), 21-32. https://papers.ssrn.com/sol3/papers.cfm?abstract_id=3154728

Sandalcılar, A. R., \& Yalman, İ. N. (2012). Türkiye'de Dış Ticaretteki Serbestleşmenin İşgücü Piyasaları Üzerindeki Etkileri. Eskişehir Osmangazi Üniversitesi İktisadi ve İdari Bilimler Dergisi, 7(2), 49-65. https://dergipark.org.tr/tr/download/article-file/65451

Sarı, A. (2008). Parasalcı Görüşe Göre Türkiye'de Ödemeler Bilançosu Dengesinin Sağlanmasında Otomatik Denkleşme Mekanizmalarının Etkinliği. Cumhuriyet Üniversitesi İktisadi ve dari Bilimler Dergisi, $\quad 9(2), \quad 1-12$. http://kutuphane.dogus.edu.tr/mvt/pdf.php?pdf=0002571\&lng=0

Seyidoğlu, H. (2013). Uluslararası İktisat Teori ve Politika. İstanbul: Güzem Yayıncılık.

Tarı, R. (2010). Ekonometri (6. Baskı). Kocaeli: Umuttepe Yayınları.

https://evds2.tcmb.gov.tr/index.php?/evds/serieMarket, (19.09.2018).

http://www.tuik.gov.tr/PreTablo.do?alt_id=1054 (8.10.2018).

https://biruni.tuik.gov.tr/disticaretapp/menu.zul (19.01.2018). 